\title{
Assessment of the effect of cocoa mosquito mirid true bug, Helopeltis sp. (Hemiptera: Miridae) on the cocoa (Theobroma cacao L.) production in Cameroon (Central Africa)
}

Raymond Joseph MAHOB ${ }^{1,2 *}$, Pierre Boris Nsoga ETAM ${ }^{1}$, Luc DIBOG $^{2}$, Régis BABIN $^{3,4}$, Audrey Valtery VOULA ${ }^{2}$, Didier BEGOUDE ${ }^{2}$, Yvan Gaétan Fotso TOGUEM ${ }^{1}$, Laurent BALEBA ${ }^{2}$, Pierre André Owona NDONGO ${ }^{2}$ and Charles Félix Bilong BILONG ${ }^{1}$

${ }^{I}$ University of Yaoundé I, P.O Box 812, Yaoundé, Cameroon; ${ }^{2}$ Institute of Agricultural Research for Development (IRAD), P.O Box 2067, Yaoundé, Cameroon; ${ }^{3}$ International Centre of Insect Physiology and Ecology (ICIPE), P.O. Box 30772-00100, Nairobi, Kenya; ${ }^{4}$ Centre de Coopération Internationale en Recherche Agronomique pour le Développement (CIRAD), UPR Bioagresseurs, F-34398 Montpellier, France.

*Corresponding author; E-mail: raymondmahob@gmail.com, Tel.: (+237)679 1876 46/695926200

\section{ACKNOWLEDGEMENTS}

We thank the Institute of Agricultural Research for Development (IRAD) for providing financial and logistic supports.

\begin{abstract}
The impact of mirid true bugs on cocoa production is widely assessed for Sahlbergella singularis and Distantiella theobroma species in the cocoa growing area in Africa. No study has been focused on the impact of another common mirid species in cocoa farming, such as Helopeltis sp., on the cocoa productivity. Thus, the main objective of this work was to assess the effect of Helopeltis sp. attacks on cocoa productivity of ten genotypes. Observations were made on infested fruits (cherelles, immature and mature fruits) under a randomized experimental field design. A control assay was also used in our investigations. The overall results revealed that only fruits infected by mirids aborted: $80.0 \%$ for cherelles and $0.4 \%$ for immature fruits. The numbers of aborted fruits were statistically comparable between cocoa genotypes and their rates varied from 60 to $96 \%$. In contrast, ANOVA showed that the feeding lethal punctures of Helopeltis sp. were significantly $(\mathrm{p}<5 \%)$ different between fruits of the tested cocoa genotypes; the mean values ranged from $41.5 \pm 5.5$ to $76.0 \pm 4.6$ and were classified in three homogenous groups, with a significant sensitivity of clone/hybrids T79/501, UPA143 x SNK64 and T79/501 x SNK413 compared with clone SNK16. The proposal of including Helopeltis sp. as one of the most important pest in cacaoculture is discussed.

(C) 2018 International Formulae Group. All rights reserved.
\end{abstract}

Keywords: Cocoa genotypes, production, impact, attacks, mirids, Helopeltis sp.

\section{INTRODUCTION}

Cocoa is one of Cameroon's main export crops (Jagoret, 2011). According to the International Cocoa Organization, this commodity represents $30 \%$ of the Gross Domestic Product in the Agricultural Products Subsector for Export and Processing. Cocoa production increased from 180,000 to 232 , 000 metric tons from the year 2005 to 2015 (Anonymous, 2014, 2015). Despite this temporal increasing yield, cocoa production per hectare remains low, 250 to 350 kilograms (Jagoret, 2011) compared to other great producing countries such as Côte d'Ivoire 
where the yields per hectare ranged from 260 to 600 kilograms (Assiri Assiri et al., 2012).

Cocoa production is constrained by several factors including aged trees, declining soil fertility levels, poor maintenance practices, predominance of old farmers (Jagoret, 2011) and attack by pests and diseases (Dormon, 2006; Sonwa et al., 2005, 2008; Mahob et al., 2014). Mirids have been reported as the main pest for cacaoculture (Dibog et al., 2008; N'Guessan et al., 2010; Anikwe et al., 2009, 2015; Adu-Acheampong et al., 2014; Mahob et al., 2011, 2014, 2015). Apart from species belonging to the Helopeltis genus which are confined only on cocoa pods (Entwistle, 1972), mirids feed on fruits, twigs/branches, chupons, shoots and trunks of their host plant. The feeding activities of mirids are characterized by (1) the direct effects such as dark markings or lesions (commonly called cankers), the black spots, the dry leaves and in some cases the stagheaded cocoa (i.e. cocoa trees with numerous small crown branches but forming a poor canopy because of the absence of the leaves) and these last symptoms were generally observed or more prevalent where cocoa is growing without shade (Entwistle, 1972); (2) the indirect effects due to the invasion of the resulting lesions by the wound parasitic fungi such as Lasiodiplodia spp., Albonectria spp. and Fusarium spp. leading lastly to the death of trees, commonly known as cocoa dieback (Adu-Acheampong et al., 2012, 2014; Anikwe et al., 2015). In West Africa, many taxa of pests such as Distantiella theobroma (Distant, 1909), Sahlbergella singularis Haglund, 1895, Bryocoropsis laticollis Schumacher, 1917 and Helopeltis spp. were found in cocoa farms; but two most important and/or dominant species, $D$. theobroma and $S$. singularis were widely reported as most economically prejudicial to cocoaculture (N'Guessan et al., 2010; Anikwe et al., 2009, 2015; Adu-Acheampong et al., 2014). In Central Africa and particularly in Cameroon, the same species were usually found in cocoa farms except $B$. laticollis (Yede, 2016). However, while researchers have widely studied the biology and ecology of $S$. singularis and D. theobroma in both West and Central Africa (N'Guessan and Coulibaly, 2000; N'Guessan et al., 2008,
2010; Anikwe et al., 2010;; Babin et al., 2008, 2010, 2011; Bisseleua et al., 2011), data related to mirids $(S$. singularis and $D$. theobroma only) damage are available only in West Africa (Entwistle, 1972; Ojelade et al., 2005; Anikwe, 2009). According to these authors, annual damage assessed in terms of cocoa production losses due to $S$. singularis and D. theobroma ranged from 30 to $50 \%$ without any control measures (insecticides treatments). However, to the best of our knowledge, no quantitative data are available in literature with regard to Helopeltis spp. damage, especially those concerning the cocoa production losses. Yet, collecting these data will undoubtedly improve our knowledge on the impact and/or the responsibility of this pest on the cocoa productivity. Therefore, the objective of the present work was to provide quantitative data on the effect of Helopeltis sp. attacks on the productivity of different cocoa genotypes as well as the lethal feeding punctures for infested fruits.

\section{MATERIALS AND METHODS Study site and plot description}

This study was conducted from May 2017 to January 2018, in the semideciduous rain forest of Southern Cameroon, in four cocoa blocks (60 m x $30 \mathrm{~m}$ each). Cocoa farms were located at the Institute of Agricultural Research for Development, Nkoemvone Research Station $\left(2^{\circ} 40^{\prime} \mathrm{N}\right.$ and $11^{\circ} 20^{\prime} \mathrm{E} ; 630 \mathrm{~m}$ above sea level) (Figure 1). The agronomic structures of the experimental plots as well as their vegetational composition, climatic and soil data have been previously documented by Mahob et al. (2011).

Experimental plots were the Fisher's completely randomized blocks. Plots contained: (1) different cocoa genotypes, eight clones (IMC60, SNK7, SNK10, SNK16, SNK52, SNK67, SNK181, T79/501) and five hybrids (T79/501×IMC60, T79/501×SNK413, T79/501×SNK479,

UPA143×NA33, UPA143×SNK64), (2) herbaceous species: Chromolaena odorata King \& Robinson, 1970 and Crotalaria sp. (Gramineae), Pennisetum purpureum Schumach, 1827 (Poaceae) and Mimosa invisa Martius ex Colla, 1834 and Mimosa pudica Linné, 1753 (Mimosaceae), and (3) shade trees such as 
Cassia spectabilis DC. (Fabaceae), Inga edulis (Vellozo) Martius (Fabaceae) and Maesopsis sp. (Rhamnaceae). The study plots were chosen on the basis of the presence of well-known cocoa genotypes, which present all fruit stages and which have not been treated for at least four years.

\section{Experimental design}

The design was completely randomized with five replications for each cocoa clone and/or hybrid per trial. Fruits of ten genotypes, five clones (IMC60, SNK7, SNK10, SNK16, T79/501PA138) and five hybrids (T79/501×IMC60, T79/501×SNK413, T79/501×SNK479, UPA143×NA33, UPA $143 \times$ SNK479) were infested by mirids, one individual per fruit, on the basis of their high productivity compared with three others (SNK52, SNK67, SNK181) during the trial period. Fruits chosen for assay previously showed good physiological growth and were free from mirid bites (i.e. fruits without any black spots). Three different growth stages of fruits (Young/cherelle, immature and mature) were considered in this work according to Niemenak et al. (2010) and our observations of the internal cavity, after dissection. These observations were based on the physiological/phenological state of the seeds. According to Niemenak et al. (2010) and our observations, the internal cavity of the cherelle (stage 1) does not have cocoa beans or seeds and the thickness of its husk measures 6 to $9 \mathrm{~mm}$ while immature (stage 2) and mature fruits (stage 3) have the seeds being or completely physiologically formed respectively; the thickness of their husk measures 9 to $16 \mathrm{~mm}$ for stage 2 and 13 to 25 $\mathrm{mm}$ for stage 3 . For each fruit stage and selected cocoa genotype, 10 specimens were infested per replication. A control (clothing sleeve without mirid) was also set up per batch. Larvae of stages 4,5 and imagos of mirids obtained from field collection and the rearing house (insectarium) of IRAD were used for fruits infestation, after a fasting period of 24 hours in the entomology laboratory of IRAD at Nkoemvone station. Young larvae (stages 1, 2 and 3) were excluded from this study due to their vulnerability for field work. Fruits selected for assays were previously confined in cloth sleeves $(20 \times 10 \mathrm{~cm}$ for cherelles, $30 \times 20 \mathrm{~cm}$ for immature and $40 \times 30 \mathrm{~cm}$ for mature fruits) to avoid any exogenous bias; then each sleeve was partially opened to allow infestation of fruits (Figure 2). For each infested fruit, mirids were removed after 15 days post-infestation.

\section{Evaluation of aborted fruits}

The evaluation of the aborted fruits was carried out during 15 days for cherelles and immature fruits, and 30 days for mature/ripe ones because of their differential susceptibility to mirid attacks (Yede et al., 2012) and phenologic cycle of fruits (Niemenak et al., 2010). The daily number of aborted fruits per stage, genotype and assay were counted. A final score was the cumulative number of aborted fruits recorded for each stage per genotype.

\section{Evaluation of the number of lethal feeding punctures of mirid's to fruits}

The number of lethal feeding punctures of mirids has been expressed by counting the black spots on the surface of the husk of each aborted fruits per genotype and category. Mirid damages on fruits were characterized by the presence of black spots on their surface (Yede et al., 2012).

\section{Data analysis}

The cumulative numbers of aborted fruits per stage and genotype, as well as the lethal feeding punctures were computed for each treatment (mirid infestation and control) using STATISTICA software (STATISTICA, 2011, Version 10). Mean numbers of aborted fruits and lethal feeding punctures were separated by ANOVA using STATISTICA via the General Linear Model (GLM) procedure. The mean values for pairwise comparisons were compared and ranked using Newman-Keuls post-hoc test. Data of immature and mature/ripe fruits for both treatments as well as those of cherelles for the control assay were excluded from the statistical analysis because no or very few aborted fruits were recorded. The differences were deemed to be significant when $p<5 \%$. 

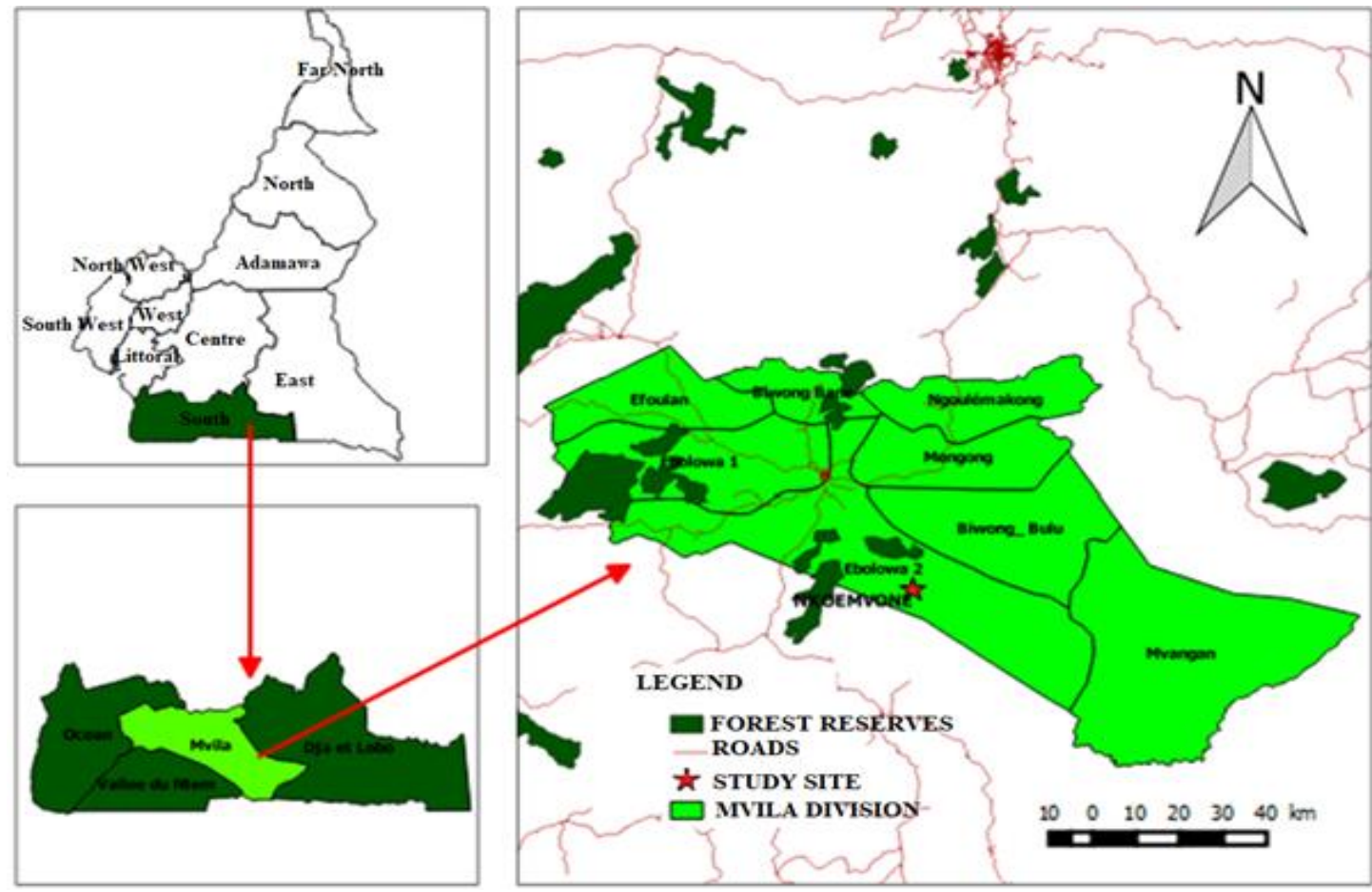

Figure 1: Geographic localization of the study site.
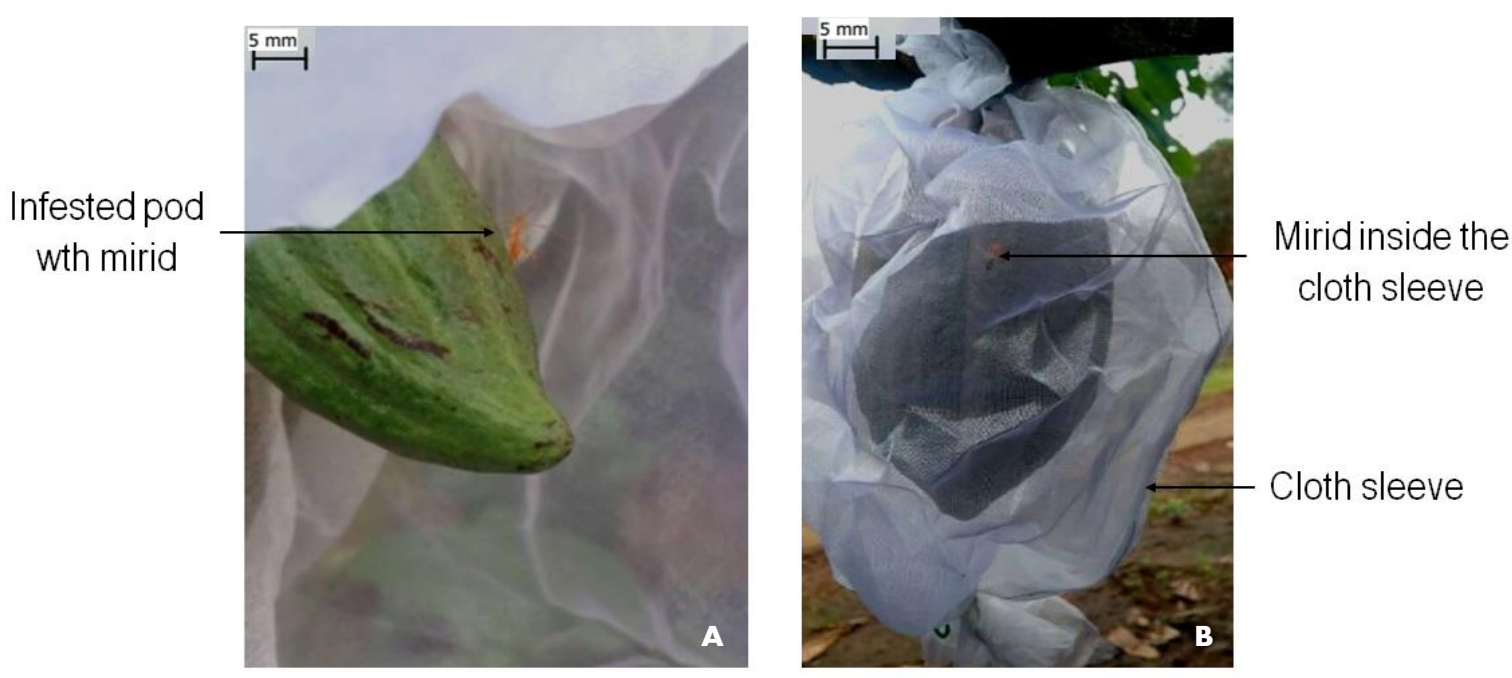

Figure 2: Protocol of fruits infestation with mirids: A) beginning of fruits infestation with partial opening of the cloth sleeve protecting the infested fruit B) post infestation of fruit with complete closure of the cloth sleeve. 


\section{RESULTS}

\section{Overall}

The general results of the descriptive analysis revealed that 402 fruits aborted out of the 500 infested by mirids per growth stage, either 400 for cherelles $(80.0 \%$ of the total) and $2(0.4 \%$ of the total $)$ for immature fruits. No aborted fruit has been recorded in the infested fruits of stage 3 and the control. Damages due to mirids in most cases for stage 2 and all cases for stage 3 of the development fruits were superficial and characterized by the presence of black spots on pods.

Assessment of the mean numbers of aborted cherelles per cocoa genotype

The mean numbers of aborted cherelles numerically varied from $0.60 \pm 0.11$ for T79/501×IMC60 to $0.96 \pm 0.05$ for SNK10 (Figure 3); but no significant difference $\left(F_{(9,40)}\right.$ $=1.64 ; p=0.11)$ was found between the tested cocoa genotypes in terms of aborted cherelles due to Helopeltis sp. attacks (Figure $3)$.

\section{Evaluation of the number of mirids lethal feeding punctures for cherelles}

The numbers of the mirids lethal feeding punctures for cherelles varied from 8 to 115 punctures for cocoa genotypes UPA143×SNK64 and T59/501xIMC60 respectively (Table 1). Significant differences $\left(F_{(0,389)}=962.14 ; \quad p<0.0001\right)$ were found between mean numbers of the Helopeltis sp. lethal feeding punctures on cherelles among the different cocoa genotypes tested (Table 1). Cocoa genotypes sensitivity/tolerance to mirid attacks can be classified in three different groups, with significant sensitivity of clone/hybrids T79/501, UPA143×SNK64 and T79/501×SNK413 compared with clone SNK16. The others clones/hybrids revealed themselves comparable sensitivity/tolerance as well as with the previous ones in some cases (Table 1).

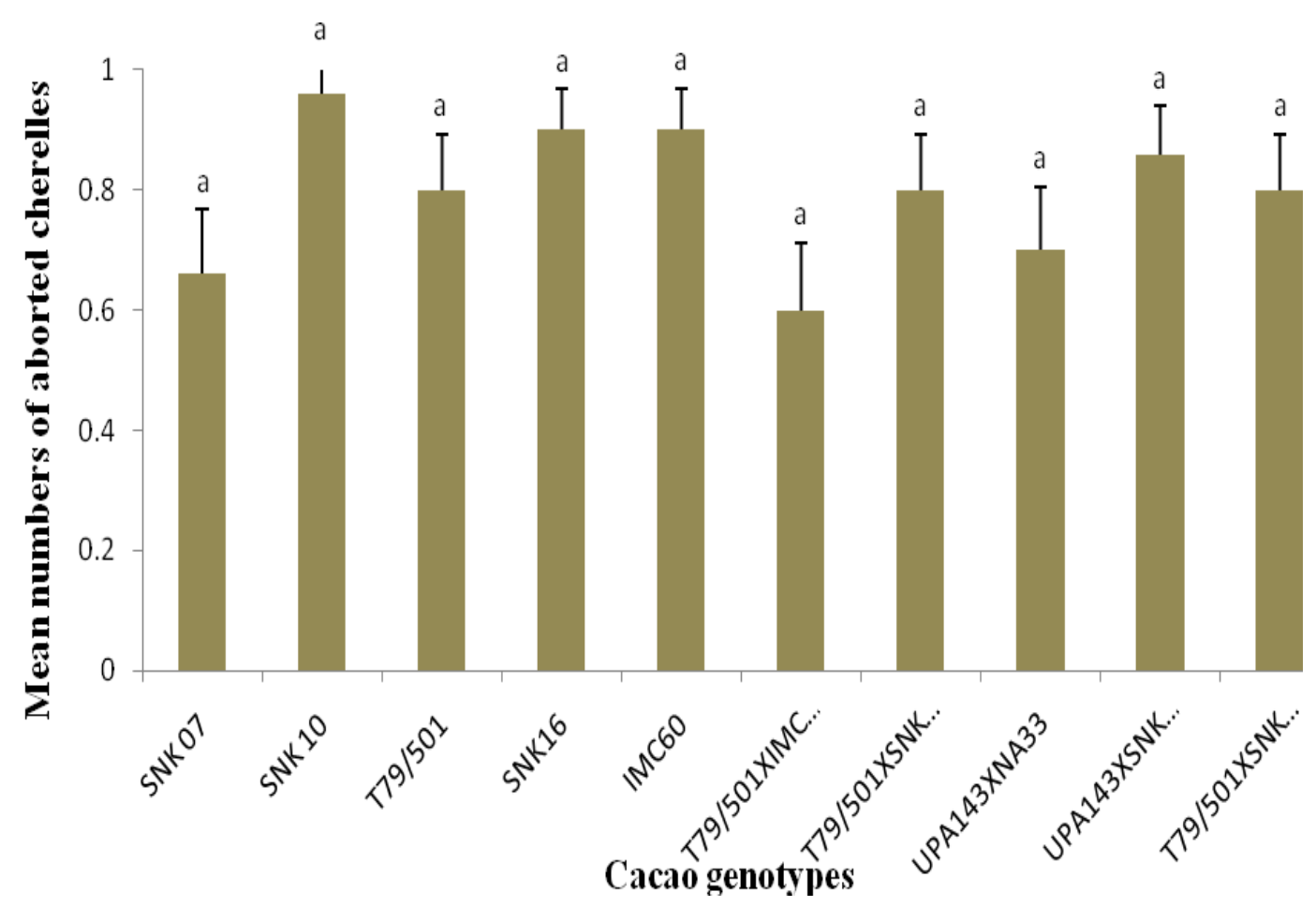

Figure 3: Comparison of the aborting cherelles (means \pm SE) in function of cocoa genotype tested, after mirid infestations. 
Table 1: Comparison of the lethal feeding points numbers (means \pm SE) in function of cocoa genotypes, including the minimum and maximum values of studied parameter.

\begin{tabular}{|c|c|c|c|c|}
\hline \multirow{2}{*}{ Genotype } & \multicolumn{3}{|c|}{ Number of lethal feeding points } & \multirow{2}{*}{$\begin{array}{c}\text { Means grouping according to } \\
\text { Newman test }\end{array}$} \\
\hline & Min & Max & Means $\pm \mathrm{SE}$ & \\
\hline UPA143XSNK64 & 8 & 78 & $41.5 \pm 5.5$ & $\mathrm{~B}$ \\
\hline $\mathrm{T} 79 / 501$ & 20 & 80 & $46.2 \pm 4.7$ & $\mathrm{AB}$ \\
\hline T79/501XSNK413 & 13 & 90 & $49.1 \pm 7.5$ & $\mathrm{AB}$ \\
\hline UPA143XNA33 & 13 & 86 & $56.6 \pm 6.4$ & $\mathrm{ABC}$ \\
\hline IMC60 & 29 & 91 & $58.4 \pm 4.6$ & $\mathrm{ABC}$ \\
\hline SNK 10 & 21 & 112 & $58.8 \pm 6.0$ & $\mathrm{ABC}$ \\
\hline T79/501XSNK479 & 15 & 98 & $61.4 \pm 5.4$ & $\mathrm{ABC}$ \\
\hline SNK 07 & 18 & 115 & $67.6 \pm 8.3$ & $\mathrm{AC}$ \\
\hline T79/501XIMC & 30 & 115 & $70.3 \pm 6.6$ & $\mathrm{AC}$ \\
\hline SNK16 & 45 & 109 & $76.0 \pm 4.6$ & $\mathrm{C}$ \\
\hline
\end{tabular}

Means followed by different letters in the most right column were significantly different at $\mathrm{P}<5 \%$, according to Newman-Keuls test. SE: Standard error, Min: Minimum, Max: Maximum.

\section{DISCUSSION}

Significant production losses were recorded in the attacks of cherelles by Helopeltis sp.: $80 \%$ of the total number of infested fruits. This result shows that this species is also an important pest to cocoa trees in terms of the cocoa productivity losses, and this support the assertion that mirids are very prejudicial economically to cocoa farming without any control measure (Entwistle, 1972; Dibog et al., 2008; N'Guessan et al., 2010; Anikwe et al., 2009, 2015; Adu-Acheampong et al., 2014; Mahob et al., 2011, 2014). Taking into consideration the cocoa genotypes, our results numerically varied from 0.60 to 0.96 i.e. $60 \%$ to $96 \%$ (Figure 3). These values differ from those (30 to 50\%) of S. singularis and $D$. theobroma obtained in cocoa farms in West Africa (Entwistle, 1972; Ojelade et al., 2005; Anikwe, 2009). This numerical discrepancy should be due to genetic determinism and this substantially highlights the divergence in the susceptibility/ tolerance/resistance of different cocoa plant varieties to mirid attacks (Sounigo et al., 2003; Dibog et al., 2008; N'Guessan et al., 2008, 2010), although the mechanisms involved in the study of this parameter (susceptibility/tolerance to mirid attacks) in the host plant are poorly understood.

Helopeltis sp. attacks have presented no effect on immature and mature fruits, except the presence of black spots on the cocoa husk. This result departs from the hypothesis of Padi (1997) that fruits of three months at most (i.e. cherelles and immature fruits according to Niemenak et al. (2010)) have reduced chance of surviving to mirid attacks. The keystone to explain this situation would undoubtedly be linked to the phenology of cocoa fruits, although the mechanisms involved remain to be clarified. Indeed, the internal cavity of cherelles contains a zygote attached to the husk with the preliminary development of the embryo (Niemenak et al., 2010). Conversely, immature and mature fruits are respectively the intermediate and final growth stages; their internal cavities contain ripening and/or fully mature cocoa beans with nucleus located in the pericarp (Loor Solorzano, 2007). Moreover, according to Loor Solorzano (2007) and our observations in the present work, the husk of cherelle is less thick (7.5 $\mathrm{mm}$ in average) and 
tender due to the lack of lignin; therefore it is permeable to liquid diffusion, such as the toxic saliva of mirids. In contrast, the husk of immature and mature fruits is thicker, 12.5 $\mathrm{mm}$ and $19 \mathrm{~mm}$ respectively; it is also hard due to the presence of lignin and therefore impermeable to liquid diffusion. When feeding on cacao trees, mirids inject their toxic saliva (Willians, 1954) in the host tissues at a depth that is less than $2 \mathrm{~mm}$ through their short (1.7 $\mathrm{mm}$ long on average) rostrum (Delvare and Alberlenc, 1989). Saliva injected by mirids has the hemolytic effects, diffuses right to the zygote through the permeable husk of cherelles, causing the destruction of the latter and consequently the death/abortion of the infested cherelles. In contrast, immature and mature/ripe fruits prevent the diffusion of the mirid's saliva injected into the host tissues. Due to their imperviousness, mirids damage are thus restricted to the surface of the husk of the infested pod, and appear as black spots. Our findings undoubtedly highlight the differential sensitivity of the fruits of stage 1 (i.e. cherelles) compared with both stages 2 (i.e. immature) and 3 (i.e. mature) of fruits to mirid, especially in Helopeltis sp. attacks, and support previous works of Yede et al. (2012) carried out in cocoa plantations in the Centre Region of Cameroon, where hexapod infestations induced 4 to $60 \%$ abortion of cherelles against none for ripe fruits. However, numerically our results discrepancy from those obtained by Yede et al. (2012) and Bos et al. (2007) in the Indonesian cocoa plantations, where physiological abortions of cherelles, commonly called wilt, caused 50\% of the total cocoa productivity losses. This numerical divergence is explained on the one hand by the fact that Bos et al. (2007) and Yede et al. (2012) conducted their works under different environmental conditions; on the other hand, cocoa genotypes observed by these authors were different from ours. This situation confirms the fact that cocoa varieties have different susceptibility/tolerance/ resistance to mirid infestations (Sounigo et al.,
2003; Anikwe et al., 2009; N'Guessan et al., 2008, 2010).

Ndoumbè-Nkeng and Sache (2003), Ndoumbè-Nkeng et al. (2004) and Yede et al. (2012), working in the cocoa farms of the Centre Region in Cameroon, reported that black pod disease cause the important production losses per year, ranged from 12 to $100 \%$ in case of no chemical (fungicides) treatments. As far as stramenopile genus (Phytophthora) is concerned, the percentages of fruits mortality due to this disease were similar to those obtained in our study. These results show that cocoa farming in Cameroon is confronted to two major constraints: Black pod rot and mirids, which constitute up to date, an economically serious pest to cocoaculture. This is in conformity with previous studies conducted by Varlet and Berry (1997) and Mahob et al. (2014) in Cameroon. However, it should be noted that Helopeltis sp. causes cherelles mortality only, while black pod rot causes mortality at all stages of the fruit development; for that reason, it is though that black pod disease could be an economically most important than mirids, although data to confirm or refute this hypothesis remain to be collected in different growing cocoa area.

From our investigations, the numbers of lethal feeding punctures due to mirids were different amongst the cocoa genotypes tested. This result suggests that albeit the susceptibility/tolerance of cherelles of our cocoa genotypes (cherelles) to mirid attacks was comparable in general, the mean numbers of feeding punctures were significantly different; the minimal and maximal values were observed for UPA143×SNK64 and SNK07 then for SNK16. This situation could be linked to the intrinsic characteristics of the different cocoa genotypes tested (e.g. physical structure of fruits, composition of primary and secondary metabolites of fruits, etc.); it also confirms the recognized intra and interspecific susceptibility of biological populations to exogenous aggressions, such as mirid attacks to cocoa trees (Sounigo et al., 2003; Anikwe et al., 2009; N'Guessan et al., 2008, 2010). 


\section{Conclusion}

At the end of our investigations, Helopeltis sp. is economically a major pest of cocoa farm, as its homologous $D$. theobroma and $S$. singularis, with regards of the significant cocoa production losses (60 to 96\% according to cocoa genotypes), especially fruits of stage 1 currently called cherelles. The infestation by this pest has no economic impact on immature and mature fruits, but leads to superficial damage that is characterized by the presence of black spots on the husk of the infested fruits. The sensitivity/tolerance of the cocoa genotypes tested to mirid attacks are comparable with regards of the rate of mortality/abortion of cherelles. Our finding suggests that all the cocoa genotypes tested are equally sensitive/tolerant to mirid attacks. This result could be taking into consideration in breeding programs of plant varieties against mirids, especially Helopeltis sp. Cocoa genotypes tested are also differently susceptible/tolerant to the feeding mirid bites. Two genotypes out of ten tested, UPA143XSNK64 and SNK16, are the most and less sensitive/tolerant respectively for feeding lethal punctures of mirids. This new data improves our understanding of the field ecology of mirids and highlights responsibility of Helopeltis sp. on cocoa production losses. Therefore, this study presents evidence of the negative impact of mirids on cocoa productivity and justifies cocoa mirid control recommendations such as chemicals used in the integrated pest management (IPM) against this pest under field conditions to protect fruits on cacao trees, especially cherelles, and finally to optimize the annual cocoa yields.

\section{COMPETING INTERESTS}

The authors declare that they have no competing interests.

\section{AUTHORS' CONTRIBUTIONS}

MRJ, DL, BR, BD and BBCF conceived and designed research. MRJ, NEPB, AVV, FTYG, BL and ONPA conducted experiments. MRJ were involved in the data analysis. MRJ wrote the manuscript and the co-authors reviewed it. BD, DL, BL and ONPA also provided finance and logistics during the study. All authors read and approved the manuscript.

\section{ACKNOWLEDGEMENTS}

Support from Hermine MAHOT, Irène NKOTTO and Damien Eyenet was especially valuable in the realization of this study. Special thanks to Professor Gideon Ajeagah for his contribution to the scientific writing of this paper.

\section{REFERENCES}

Adu-Acheampong R, Archer S, Leather S. 2012. Resistance to dieback disease caused by Fusarium and Lasiodiplodiaspecies in cocoa (Theobroma cacao L.) genotypes. Exp. Agric., 48: 85-98. DOI: https://doi.org/10.1017/S1742758413000 441

Adu-Acheampong R, Jiggins J, van Huis A, Richmond Cudjoe A, Johnson V, SakyiDawson O, Ofori-Frimpong K, OseiFosu P, Tei-Quartey E, Jonfia-Essien W, Owusu-Manu M, Karikari Addo NMS, Afari-Mintah C, Amuzu M, Nyarko EkuXN, Quarshie ETN. 2014. The cocoa mirid (Hemiptera: Miridae) problem: evidence to support new recommendations on the timing of insecticide application on cocoa in Ghana. Int. J. Trop. Insect Sci., 34: 5871.

DOI: http://dx.doi.org/10.1017/S17427584130 00441

Anikwe JC. 2009. Evaluation of Field Damage and Chemical Control of Outbreak of Sahlbergella Singularis Haglund in a Cocoa Plantation in Ibadan, Nigeria. Am.-Eurasian J. Sustain. Agric., 3(1): 19-23.

Anikwe JC, Omoloye AA, Aikpokpodion PO, Okelana FA, Eskes AB. 2009. Evaluation of resistance in selected cocoa genotypes to the brown cocoa mirid, Sahlbergella singularis Haglund 
in Nigeria. Crop prot., 28(4): 350-355. DOI: 10.1016/j.cropro.2008.11.014

Anikwe JC, Omoloye AA, Okelana FA. 2010. The population dynamics of the brown cocoa mirid, Sahlbergella singularis Haglund in Ibadan, Nigeria. Afri. J. Food Agri. Nutr. Dev., 10: 2772-2783.

Anikwe JC, Otuonye HA. 2015. Dieback of cocoa (Theobroma cacao L.) plant tissues caused by the brown cocoa mirid Sahlbergella singularis Haglund (Hemiptera: Miridae) and associated pathogenic fungi. Int. J. Trop. Insect Sci., 35: 193-200. DOI: 10.1017/S1742758415000120

Anonymous. 2014. Plan de relance et de développement des filières cocoa et café du Cameroun horizon 2020. Accessed at http://www.mays-mouissi.com/wpcontent/uploads/2015/05/planCocoaCafe -Cameroun-2015-2020.pdf on $30 / 12 / 2017$

Anonymous. 2015. Annual Report 2014/2015 of International Cocoa Organization (ICCO). Accessed at http://www.icco.org/about-us/iccoannual-report.html on 30/11/2017

Assiri Assiri A, KACOU EA, ASSI FA, Ekra KS, Dji KF, Couloud JY, Yapo AR. 2012. Rentabilité économique des techniques de réhabilitation et de replantation des vieux vergers de cocoayers (Theobroma cacao L.) en Côte d'Ivoire. J. Anim. Plant Sci., 14 (2): 1939-1951.

Babin R, Bisseleua BHD, Dibog L, Lumaret JP. 2008. Rearing method and life table data for the cocoa mirid bug Sahlbergella singularis Haglund (Hemiptera: Miridae). J. Appl. Entomol., 132: 366-374.

DOI:

http://dx.doi.org/10.1111/j.14390418.2008.01273.x

Babin R, Ten Hoopen GM, Cilas C, Enjalric F, Yede, Gendre P, Lumaret JP. 2010. Impact of shade on the spatial distribution of Sahlbergella singularis Hagl. (Hemiptera: Miridae) in traditional cocoa agroforests. Agric. Forest
Entomol., 12: 69-79. DOI: 10.1111/j.1461-9563.2009.00453.x

Babin R, Anikwe JC, Dibog L, Lumaret JP. 2011. Effects of cocoa tree phenology and canopy microclimate on the performance of the mirid bug Sahlbergella singularis. Entomol. Exp. Appl., 141: 25-34. DOI: 10.1111/j.15707458.2011.01164.x

Bisseleua HBD, Yede, Vidal S. 2011. Dispersion models and sampling of cocoa mirid bug Sahlbergella singularis (Hemiptera: Miridae) on Theobroma cacao in Southern Cameroon. Environ. Entomol., 40: 111-119. DOI: 10.1603/EN09101

Bos MM, Steffan-Dewenter I, Tscharntke T. 2007. Shade tree management affects fruit abortion, insect pests and pathogens of cocoa. Agric. Ecosyst. Environ., 120: 201-205.

DOI: 10.1016/j.agee.2006.09.004

Delvare G, Aberlenc HP. 1989. Les Insectes d'Afrique et d'Amérique Tropicale: Clés pour la Reconnaissance des Familles. CIRAD/PRIFAS: Montpellier, France; $302 p$.

Dibog L, Babin R, Amang a Mbang J, Decazy B, Nyassé S, Cilas C, Eskes A. 2008. Effect of genotype of cocoa (Theobroma cacao) on attractiveness to the mirid Sahlbergella singularis (Hemiptera: Miridae) in the laboratory. Pest Manag. Sci., 64: 977-980. DOI: http://dx.doi.org/10.1002/ps.1589

Dormon ENA. 2006. From a technology focus to innovation development: the management of cocoa pests and diseases in Ghana. $\mathrm{PhD}$ thesis, Wageningen University, The Netherlands. 216p.

Entwistle PF. 1972. Pests of Cocoa. Longman Group Ltd: London, United Kingdom.

Jagoret P. 2011. Analyse et évaluation de systèmes agroforestiers complexes sur le long terme : application aux systèmes de culture à base de cocoayer au Centre Cameroun. Thèse de Doctorat de l'Université de Montpellier SupAgro, Montpellier, $288 \mathrm{p}$. 
Loor Solorzano RG. 2007. Contribution à l'étude de la domestication de la variété de cocoayer Nacional d'Équateur : recherche de la variété native et de ses ancêtres sauvages. Thèse de Doctorat de 1'Université SupAgro de Montpellier, Montpellier, $201 \mathrm{p}$.

Mahob RJ, Babin R, Ten Hoopen GM, Dibog L, Yede, Hall D, Bilong Bilong CF. 2011. Field evaluation of synthetic sex pheromone traps for the cocoa mirid Sahlbergella singularis (Hemiptera: Miridae). Pest Manag. Sci., 67: 672-676. DOI : 10.1002/ps.2107

Mahob RJ, Ndoumbè-Nkeng M, Ten Hoopen GM, Dibog L, Nyassé S, Rutherford M, Mbenoun M, Babin R, Amang A Mbang, J, Yede, Bilong Bilong, CF. 2014. Pesticides use in cocoa sector in Cameroon: characterization of supply source, nature of actives ingredients, fashion and reasons for their utilization. Int. J. Biol. Chem. Sci., 8(5): 1976-1989. DOI: http://dx.doi.org/10.4314/ijbcs.v8i5.3

Mahob RJ, Baleba L, Yede, Dibog L, Cilas C, Bilong Bilong CF, Babin R. 2015. Spatial distribution of Sahlbergella singularisHagl. (Hemiptera: Miridae) populations and their damage in unshaded young cocoa-based agroforestry systems. Int. J. Plant Anim. Environ. Sci., 5: 121-131.

Motamayor JC, Risterucci AM, Lopez PA, Ortiz CF, Moreno A, Lanaud C. 2002. Cocoa domestication, in: the origin of the cocoa cultivated by the Mayas. Heredity, 89: 308-386. DOI: 10.1038/sj.hdy.6800156

N'Guessan FK, Coulibaly N. 2000. Dynamique des populations des mirides et de quelques autres déprédateurs du cocoayer dans la region Ouest de la Côte d'Ivoire. Actes de la $13^{\text {ème }}$ Conférence Internationale sur la Recherche Cocoayère, Kota Kinabalu, Sabah, Malaysia, 425-435.

N'Guessan KF, N'Goran JAK, Eskes AB. 2008. Resistance of cocoa (Theobroma cacao L.) to Sahlbergella singularis (Hemiptera: Miridae): investigation of antixenosis, antibiosis and tolerance. Int. J. Trop. Insect Sci., 28(4): 201-210. DOI: $10.1017 / \mathrm{S} 1742758408184740$

N'Guessan KF, Lachenaud Ph, Eskes AB. 2010.Antixenosis as a mechanism of cocoa resistance to the cocoa mirid, Sahlbergella singularis (Hemiptera: Miridae). J. Appl. Biosci., 36: 23332339.

Ndoumbe-Nkeng M, Cilas C, Nyemb E, Nyasse S, Bieysse D, Flori A, Sache I. 2004. Impact of removing diseased pods on cocoa black pod caused by Phytophthora megakarya and on cocoa production in Cameroon. Crop Prot., 23: 415-424.

DOI: 10.1016/j.cropro.2003.09.010

Ndoumbe-Nkeng M, Sache I. 2003. Lutte contre la pourriture brune des cabosses du cocoayer au Cameroun. Phytoma, 562: $10-12$.

Niemenak N, Cilas C, Rohsius C, Bleiholder H, Meier U, Lieberei R. 2010. Phenological growth stages of cocoa plants (Theobroma sp.): codification and description according to the $\mathrm{BBCH}$ scale. Ann. Appl. Biol., 156: 13-24. DOI: 10.1111/j.1744-7348.2009.00356.x

Ojelade KTM, Anikwe JC, Idowu OL. 2005. Comparative evaluation of the miridicidal efficacy of some insecticides for the control of the brown cocoa mirid, Sahlbergella singularis, in Nigeria. Appl. Trop. Agric., 10: 46-53.

Padi B. 1997. Prospects for the control of cocoa capsids -alternatives to chemical control. In: Proceedings of the 1st International Cocoa Pests and Diseases Seminar, 6-10 November 1995: Accra, Ghana, 28-36.

Sonwa DJ, Weise S, Adesina A, Nkongmeneck AB, Tchatat M, Ndoye O. 2005. Production constraints on cocoa agroforestry systems in West and Central Africa: The need for integrated pest management and multi-institutional approaches. The Forest. Chron., 81: 345- 
349.

http://hdl.handle.net/10568/19418

Sonwa DJ, Coulibaly O, Weise SF, Akinwumi Adesina A, Janssens MJJ. 2008. Management of cocoa: Constraints during acquisition and application of pesticides in the humid forest zones of southern Cameroon. Crop Prot., 27: 1159-1164. DOI:10.1016/j.cropro.2008.02.004

Sounigo O, Coulibaly N, Brun L, N'Goran JAK, Cilas C, Eskes AB. 2003. Evaluation of resistance of Theobroma cacao L. to mirids in Côte d'Ivoire: results of comparative progeny trials. Crop Prot., 22: 615-621. DOI: 10.1016/S0261-2194(02)00244-2

Statistica 2011. StatisticaNeural Network Software (version 10.0). Inc.,Tulsa, Oklahoma: USA.

Varlet F, Berry D. 1997. Réhabilitation de la protection phytosanitaire des cocoayers et caféiers du Cameroun. Tome I : rapport principal. Cirad/Conseil interprofessionnel du cocoa et du café : Douala, Cameroun, 204p.
Williams G. 1954. Field observations on the cocoa mirids, Sahlbergella singularis Hagl. and Distantiella theobroma (Dist.), in the Gold Coast. Part III. Population fluctuations. Bull. Entomol. Res., 45: 723-744.

DOI: https://doi.org/10.1017/S0007485300033 344

Yede, Babin R, Djieto-Lordon C, Cilas C, Dibog L, Mahob R, Bilong Bilong CF. 2012. True Bug (Heteroptera) Impact on Cocoa Fruit Mortality and Productivity. J. Econ. Entomol., 105: 1285-1292. DOI : http://dx.doi.org/10.1603/EC12022

Yede. 2016. Diversité des peuplements des hémiptères dans les cacaoyères de la Région du Centre Cameroun: impact économique et essai de lute biologique. Thèse de Doctorat PhD, Université de Yaoundén I, Yaoundé, Cameroun. 174p. 